\title{
In memorium: Professor Arun Kumar Sharma
}

\author{
Umesh C. Lavania ${ }^{1} \cdot$ Bani Gajra $^{2}$
}

Published online: 9 November 2017

(C) Archana Sharma Foundation of Calcutta 2017
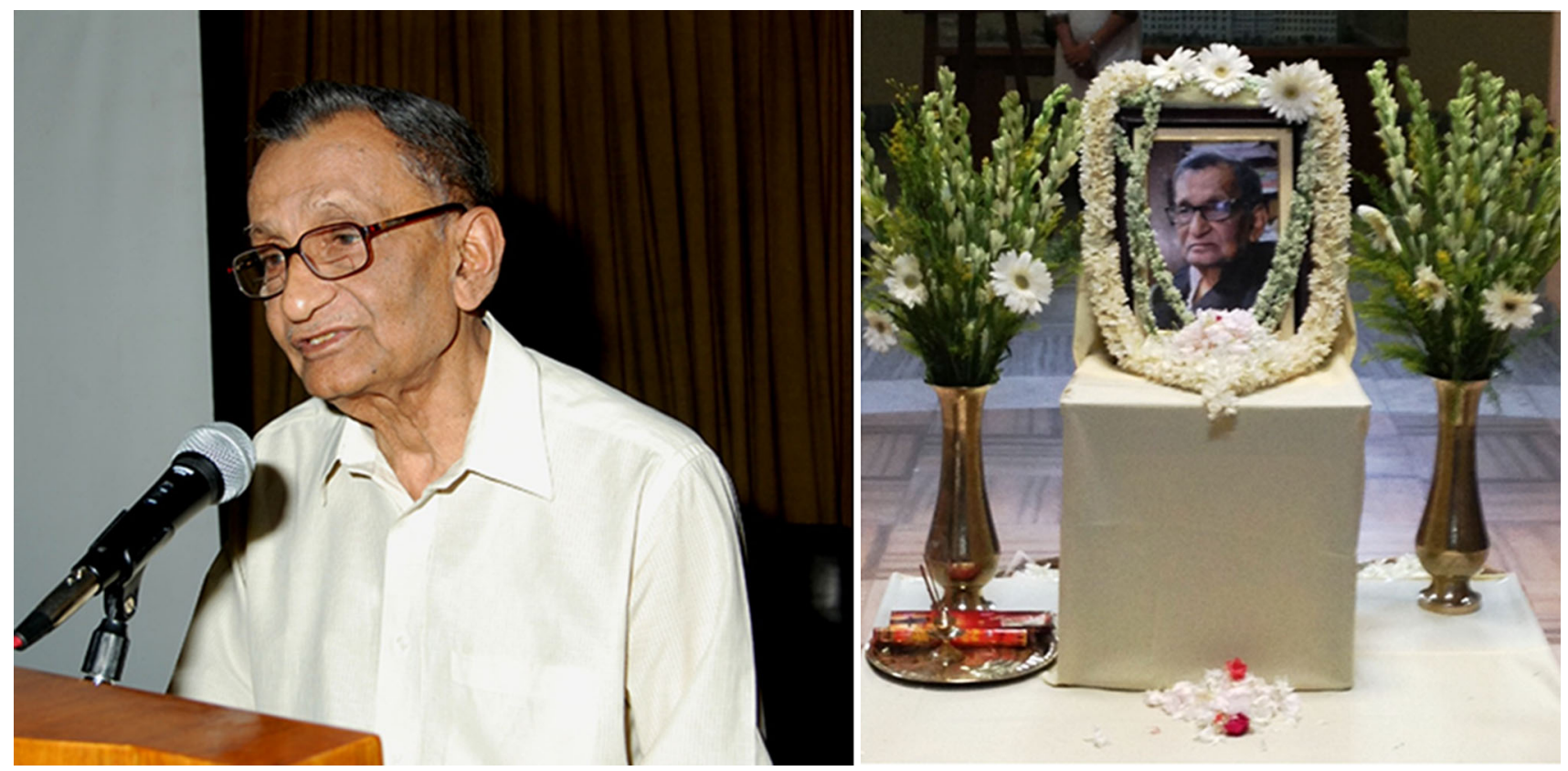

On 12th June 2017, Professor Arun Kumar Sharma, Founder Editor in Chief of The Nucleus presided over the Annual General Meeting with his usual poise and grace.

Umesh C. Lavania

lavaniauc@yahoo.co.in

Bani Gajra

gajrabani@gmail.com

1 Department of Botany, University of Lucknow, Lucknow 226007, India

2 Department of Botany, University of Calcutta, Kolkata 700 019, India
Little did any one present could believe that it would be his last meeting. Five days later, he had an ischemic stroke and was admitted to a hospital. In the following 2 weeks it appeared that he would recover but his condition deteriorated on 6th July 2017, and he breathed his last around 20:30 h leaving his students, colleagues and admirers in deep anguish. His last journey was organized by the management of Ramakrishna Mission, Belur Math, Howrah and Ramakrishna Mission Institute of Culture, Golpark, Kolkata on 7th July amidst the chanting of Vedic hymns by the reverend Maharajs of Ramakrishna Mission Institute of Culture, Golpark, Kolkata where he was living during past few years. 
Popularly known as 'AKS' among his peers and referred to as 'Sir' by his students and colleagues, Professor A.K. Sharma was born on 31 December 1924 in Calcutta to Charu Chandra Sharma and his wife Shovamoyee. He lost his father at the tender age of 8 years, and he was brought by his mother's family. The young Arun obtained the degree of BSc in 1943 with 'half free scholarship'. He completed MSc in 1945 and DSc in 1955 from the University of Calcutta.

After brief stint as a Research Assistant alongwith RS Rao and DD Awasthi at the Botanical Survey of India, AKS joined the Department of Botany of Calcutta University as a full time temporary teacher in 1947 . He was promoted as a full time Assistant Lecturer in 1948, and rose to the positions of Lecturer and Reader, finally appointed as Sir Rash Behari Ghosh Professor and Head of the Department of Botany at the University of Calcutta (1969-1980). He continued as Ghosh Professor until 1988. The Indian National Science Academy (INSA) awarded him the Golden Jubilee Research Professorship from 1985 to 1990 at the University of Calcutta. He was associated with numerous scientific bodies till the last day of his life.

Professor Sharma was an eminent scientist and the Founder Programme Coordinator of the University Grant Commission's Centre of Advanced Study in Cell and Chromosome Research in the Department of Botany, University of Calcutta. A distinguished alumnus, an accomplished venerated teacher of the University of Calcutta, he adorned the office of President of Indian National Science Academy (INSA), National Academy of Sciences India (NASI), Indian Science Congress Association (ISCA), and was accorded Jawaharlal Nehru Fellowship and National Professorship of the University Grants Commission, New Delhi.

He had photographic memory and remained active till the end completing in the process revision of the 11 volume edited series on History of Science in India jointly published by the National Academy of Sciences India, Allahabad and the Ramakrishna Mission Institute of Culture, Kolkata, the first edition of which was published in 2014. He wrote the Editorial for the August 2017 issue of The Nucleus in the second week of June 2017. A celebrated scientist and an acclaimed cytogeneticist, AKS had several distinguished professional honours to his credit including the coveted Shanti Swarup Bhatnagar Prize of the Council of Scientific and Industrial Research and the third highest civilian Award Padma Bhushan (1983) conferred on him by the President of India.

AKS had his initial training in cytology under Professor PN Bhaduri for his MSc thesis. Subsequently he carried out chromosome research and conducted studies on a wide range of problems of plant and human genetics leading to an active school of cytogenetics, cytotaxonomy and cytochemistry at the University of Calcutta. Among his seminal contributions are innovation in techniques for studying structure and behavior of chromosomes in animals, plants and human being, chromosome dynamism during speciation and chromosome behaviour in differentiated cells, expanding the horizon of chromosome studies to areas comprising genetic, molecular, cell culture, genetic toxicology and population genetics. An extended account of his scientific contributions and personal attributes has earlier been published in 2014 under the elite series 'Living Legends In Indian Science' published by Curr. Sci. 107: 522-528, 2014 (http://www.currentscience.ac.in/Volumes/ 107/03/0522.pdf).

AKS had exceptional courage at the young age of 33 to start an international journal of cytology and allied topics along with Professor Archana Sharma The Nucleus (1958). The aim of the journal was to highlight all aspects of cell and chromosome research in eukaryotes-physical and chemical, structural and functional. The journal was inaugurated in August 1958 at the International Congress of Genetics in Montreal and was attended by almost all members of the advisory board namely Professors B. P. Kaufmann, H. Kihara, A. Löve, F. Oehlkers, H. P. Riley, M.J. Sirks and J.H. Taylor. In later years, Professors T. Caspersson, C.D. Darlington, R. Haynes and Robin Holliday became members of the advisory board and remained so till their demise.

Professor Sharma authored (jointly with his wife Archana Sharma) the classic reference book Chromosome Techniques: Theory and Practice (Butterworth \& Co. Ltd, London, 1965) that went into 2 nd and 3rd editions in 1972 and 1980. The book has been extensively used throughout the world. Some other books jointly authored/ edited by the Sharmas are: Chromosomes in Evolution of Eukaryotic Groups. Vol I and II, CRC Press Inc., Boca Ratan, Florida, 1983 and 1984 respectively; Advances in Chromosome and Cell Genetics. Oxford and IBH Publishing Co. New Delhi, 1985, 1989; Chromosome Technique-A Manual. Harwood Academic Publishers, Switzerland, 1994; Plant Chromosomes-Analysis, Manipulation and Engineering. Harwood Academic Publishers, Switzerland, 1999; Methods in Cell Science. Vol 23 (No. 1-3) Special issue: Chromosome PaintingPrinciples, Strategies and Scope. Kluwer Academic Publishers, Boston, 2001; Plant Genome-Biodiversity and Evolution, Vols. 1-7 (2003-2008). Science Publishers, Enfield (NH), UK, etc.

Besides his own research activities on various domains of plant science, he had significantly contributed to the policy, planning and formulation of scientific and technical programs for different Universities as well as the Government of India for the growth of science and technology in India. 
He commanded extraordinary leadership qualities and oratorical skills befitting a true leader constantly inspiring peers, colleagues and students alike as a team leader. He always appreciated constructive difference for the sake of the best. As a constant reminder he had a Buddha painting displayed in his office room with an inscription "Believe nothing merely because you have been told it or because it is traditional or because you yourself have imagined it. Do not believe what your teacher tells you merely out of respect for the teacher. But whatever after due examination and analysis you find to be conducive to the good, the benefit, the welfare of all beings, that doctrine believe and cling to, and take it as your guide”.

He had a great faith in super powers of God, and was a strong follower of Ramakrishna Paramahamsa Deb and Swami Vivekanada. He was very closely associated with The Ramakrishna Mission, and was the Vice President of the Governing Body of the Ramakrishna Mission Institute of Culture, Gol Park, Kolkata, India and the Chairman of the Ethical Committee of the Vivekananda Institute of Medical Sciences, Ramakrishna Mission Seva Pratishthan, Kolkata, India, till his last day. His dedication to duty and sense of detachment are strongly influenced by his long association with the Ramakrishna Mission. In his final years he donated his material assets for the benefit of weaker sections and lived in the Guest House of the Ramakrishna Mission Institute of Culture, Kolkata.
The scientific community of India in general and the botanical fraternity in particular, shall remain indebted to his guidance in nurturing young talent and facilitating development of scientific infrastructure across biological and environmental disciplines. Although, the Sharmas had no biological offspring of their own, they are survived by a large band of students, grand students, great grand students and young students, who always take pride in being attributed to them.

It would not be out of place to put on record that his life companion revered Professor Archana Sharma had a great catalytic effect in synergizing his energy and intellectual output. She was the cofounder of The Nucleus and continued to effectively support the journal till her death in 2008. She left us just after the completion of the golden jubilee of The Nucleus, and 'Sir' left us while we were in the 60th year of The Nucleus, and had planned the December 2017 issue for the Diamond Jubilee. We grieve that he is not with us to see the December issue that contains articles, most of which were sent in response to his personal invitation.

Prof. A.K. Sharma was a Guru for well over seven decades. His invaluable contributions to Science will be remembered for ever. In reverence to him, all the articles contained in this 60th year Diamond Jubilee issue of The Nucleus, Vol 60, issue 3 are dedicated to his loving memory. 